\title{
Petrogenesis of alkalic and calcalkalic volcanic rocks of Mormon Mountain Volcanic Field, Arizona
}

\author{
D.A. Gust ${ }^{1, *}$ and R.J. Arculus ${ }^{2}$ \\ ${ }^{1}$ Lunar and Planetary Institute, 3303 NASA Road One, Houston, TX 77058, USA \\ ${ }^{2}$ Department of Geological Sciences, University of Michigan, Ann Arbor, MI 48109, USA
}

\begin{abstract}
The Cenozoic Mormon Mountain Volcanic Field (MMVF) of northern Arizona is situated in the transition zone between the Basin and Range and the Colorado Plateau. It is composed of alkalic to sub-alkalic basalts and calcalkalic andesites, dacites, and rhyodacites. Despite their spatial and temporal association, the basalts and the calcalkalic suite do not seem to be co-genetic. The petrogenesis of primitive MMVF basalts can be explained as the result of different degrees of partial melting of a relatively homogenous, incompatible element-enriched peridotitic source. The variety of evolved basalt types was the result of subsequent fractional crystallization of olivine, spinel, and clinopyroxene from the range of primitive basalts. Crustal contamination seems to have occurred, but affected only the highly incompatible element abundances. The formation of MMVF calcalkalic rocks is most readily explained by small to moderate amounts of partial melting of an amphibolitic lower crust. This source is LREE-enriched but depleted in $\mathrm{Rb}$ and relatively unradiogenic $\mathrm{Sr}\left({ }^{87} \mathrm{Sr} /{ }^{86} \mathrm{Sr} \sim 0.7040\right)$. Calcalkalic rhyodacites may also be derived from andesitic parents by fractional crystallization. The overall petrogenesis of the MMVF complex is the result of intra-plate volcanism where mantle-derived magmas intrude and pass through thick continental crust.
\end{abstract}

\section{Introduction}

The MMVF developed near the southwestern margin of the Colorado Plateau during the late Cenozoic (15-3 Ma). The MMVF is similar to other volcanic fields that mark the western, southern, and eastern boundaries of the Plateau [e.g. SW Utah (Lowder 1973; Best and Brimhall 1974); San Francisco Volcanic Field (Robinson 1913; Moore et al. 1976)] with respect to the variety of rock types present (alkalic basalts and calcalkalic andesites, dacites, and rhyodacites). These volcanic areas lie within the transition zone between the Basin and Range and the Colorado Plateau. This zone is characterized by numerous normal faults, high heat flow (Blackwell 1978), and a gradual thickening of the continental crust (Warren 1969), all of which might be expected to have some influence or be interrelated in

Offprint request to: D.A. Gust

* Presently at: Department of Earth Sciences, University of New Hampshire, Durham, New Hampshire 03824, USA some way with the petrogenesis of late Cenozoic lavas of this area (Lowder 1973). This paper considers the petrogenesis of MMVF and is part of a larger study of the Cenozoic volcanism of the transition zone undertaken in part to better understand the relationship between tectonism and volcanism in the region (Gust et al. 1984), and the genesis of anorogenic (in the sense of non-plate collision zone) calcalkalic magmatism.

There are several important issues in the petrogenetic history of the MMVF suite that deserve detailed discussion: 1) the origin of the variety of MMVF basalts; 2) the extent of superimposed contributions of fractional crystallization and crustal assimilation on the initial diversity of basalt compositions created by variable partial melting conditions; 3 ) the relationship between the basalts and the andesites; 4) the origin of the variety of intermediate and silicic rock types in MMVF; and 5) the importance of interaction of mantle-derived magmas with continental crust.

\section{Regional geology}

MMVF extends over about $3,500 \mathrm{~km}^{2}$ south of Flagstaff, Arizona (Fig. 1). Multiple flows of basaltic lavas, erupted from monogenetic cinder cones and NW-trending fissures, form a thin plateau-capping cover on sedimentary strata. These fissures parallel local fault trends and the margin of the Colorado Plateau (Mogollon Rim), suggesting a regional structural control on the volcanic eruptions. Mormon Mountain, the largest silicic center in the field, is composed of hornblende andesite flows overlain by dacite flows. A rhyodacite dome occurs near the southern flank of Mormon Mountain and a smaller rhyodacite dome crops out $10 \mathrm{~km}$ further south in a basaltic cinder cone. Small andesite domes occur throughout the field. The volume of basalt exceeds that of the silicic lavas, but precise estimates are difficult to make.

Basalts from Anderson Mesa and Oak Creek Canyon, delimiting the northern and western boundaries of the field, yield $\mathrm{K}-\mathrm{Ar}$ ages of $5.9 \pm 0.9 \mathrm{Ma}$ and $6.0 \pm 0.3 \mathrm{Ma}$, respectively (Damon et al. 1974). Basalts from the southern edge of the field, near Casner Butte and Pine are older (9-15 Ma, Peirce et al. 1979). A dacite from Mormon Mountain is dated at $3.1 \pm 0.1 \mathrm{Ma}$ (R.B. Moore pers. comm. 1977), and an andesite from Table Mountain in the southern part of MMVF is dated at $3.6 \pm 0.1 \mathrm{Ma}$ (T.M. Harrison pers. comm. 1980), both dates by K - Ar methods. Detailed stratigraphic relationships between different volcanic units are not clear in the field.

MMVF overlies Permian Coconino sandstone that caps a thick sequence of Paleozoic sedimentary rocks. Precambrian granites, schists, and gneisses comprise the upper crust of the Colorado Plateau. The lower crust consists of amphibolite, granulite, and eclogite as inferred from geophysical investigations (Prodehl 1970) 


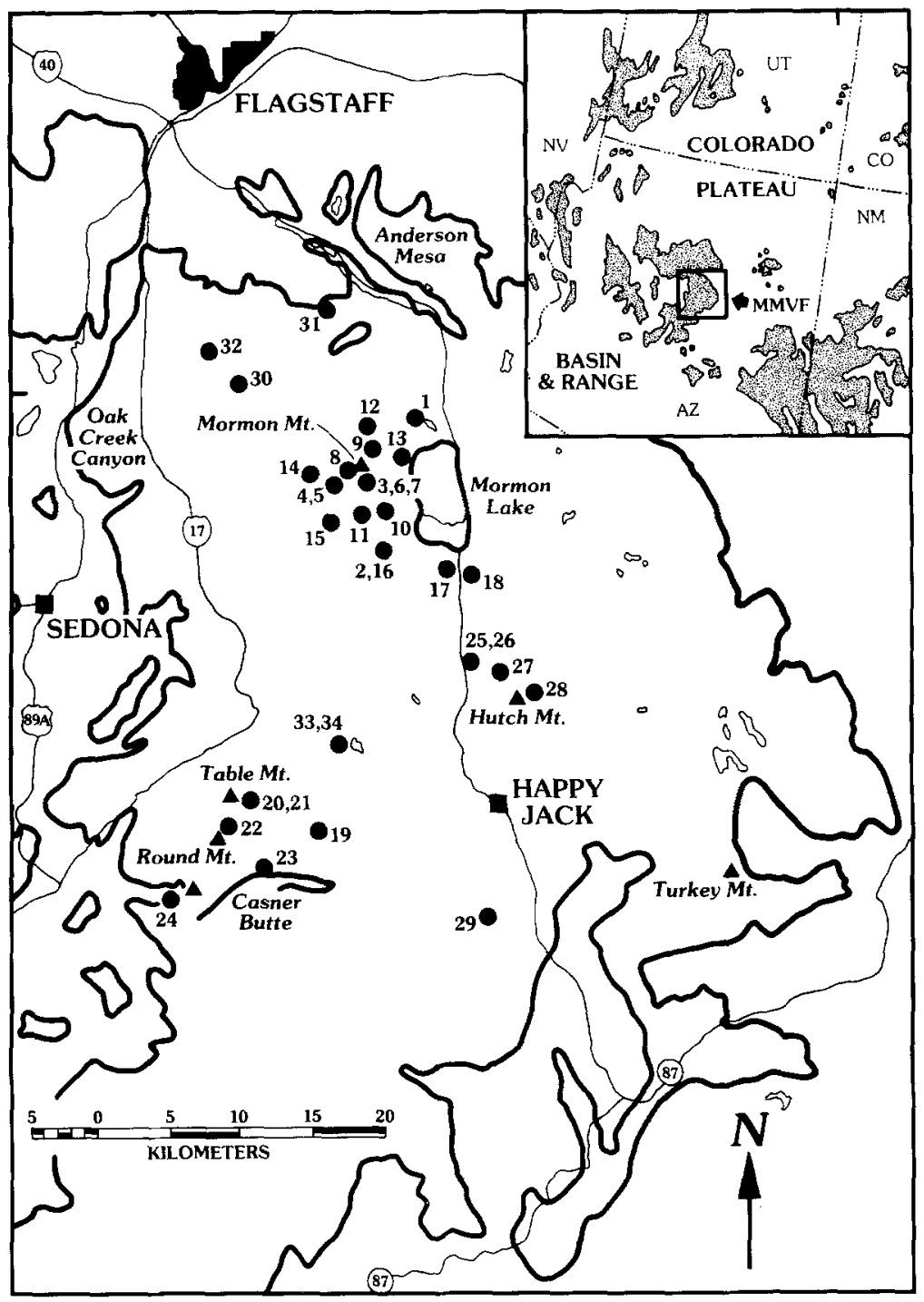

Fig. 1. Location and sample locality maps of MMVF (stippled area). The inset shows the location of MMVF with respect to the Colorado Plateau and the Basin and Range. Outlined areas are other Tertiary volcanic fields which rim the Colorado Plateau and petrological studies of high-pressure xenoliths in explosive volcanics (McGetchin and Silver 1972; Arculus and Smith 1979; Ehrenberg and Griffin 1979; Stoeser 1973; Keating et al. 1985).

\section{Petrology}

\section{Basalts}

MMVF basalts range from olivine nephelinite to olivine tholeiite with basanite and alkali olivine basalt being the most abundant. The basalts are aphanitic to fine-grained, with intersertal to intergranular textures; most are vesicular and some contain calcite or zeolite-filled amygdules. Olivine and clinopyroxene phenocrysts with euhedral spinel inclusions are common. Plagioclase phenocrysts are rare, except in hawaiites and olivine tholeiites. Modal phenocryst abundances range from $10-50 \%$, and some clinopyroxene phyric lavas could be called ankaramites.

The composition of olivine phenocrysts within the basaltic suite ranges from $\mathrm{FO}_{89}$ to $\mathrm{Fo}_{62}$. Phenocrysts of clinopyroxene are sectorand oscillatory zoned and range from diopside to salite in the basanites and some alkali olivine basalts, and diopside to augite in other alkali olivine basalts, hawaiites and olivine tholeiites (Fig. 2). Octahedral spinel inclusions in clinopyroxene and olivine range from $\mathrm{Mg}-\mathrm{Al}$-rich chromites to chromian titanomagnetites. Spinels near the forsteritic core of host olivine phenocrysts have higher $\mathrm{Mg}$ numbers and $\mathrm{Cr} /(\mathrm{Cr}+\mathrm{Al})$ ratios than spinels nearer the rim. Rare ilmenite phenocrysts or xenocrysts in basanites are magnesian - (13 wt. \% $\mathrm{MgO})$ and manganese-rich (1.3 wt. \% $\mathrm{MnO})$. Plagioclase phenocrysts $\left(\mathrm{An}_{82-70}\right)$ are small $(<2 \mathrm{~mm})$, euhedral laths often occurring as glomerocrysts with clinopyroxene.

Groundmass olivine $\left(\mathrm{Fo}_{80-43}\right)$ is partly altered to iddingsite. Groundmass clinopyroxene contains up to $11.0 \mathrm{wt} \% \mathrm{Al}_{2} \mathrm{O}_{3}$ and 2.5 wt. $\% \mathrm{TiO}_{2}$. Plagioclase laths in the groundmass are highly variable in composition, ranging from $\mathrm{An}_{89}$ to $\mathrm{An}_{37}$. Minor groundmass phase assemblages include: 1) nepheline $\left(\mathrm{Ca}_{4} \mathrm{Na}_{83} \mathrm{~K}_{13}\right)$, sanidine and alkalic residuum (basanites); 2) anorthoclase and $\mathrm{K}$-rich residuum (alkali olivine basalts); and 3 ) coexisting leucite $\left(\mathrm{Ca}_{2} \mathrm{Na}_{2} \mathrm{~K}_{96}\right)$ and nepheline $\left(\mathrm{Ca}_{10} \mathrm{Na}_{77} \mathrm{~K}_{13}\right)$ (olivine nephelinite). Apatite is ubiquitous and associated with anhedral patches of felsic-alkalic residuum. Unexsolved titanomagnetite with a limited compositional range and rare, unexsolved, $\mathrm{Mg}$ - and Mn-poor ilmenite occur in the groundmass of some basalts.

\section{Megacrysts and inclusions}

Some basanites contain megacrysts of olivine and clinopyroxene whose compositions overlap those of the most mafic phenocrysts in the lavas (Fig. 2). Three types of ultramafic inclusions are also present: 1) spinel wehrlite; 2) olivine websterite; and 3) spinel websterite. They have equigranular to poikilitic textures with minimal evidence of recrystallization and deformation. Wehrlites and olivine websterites are composed of olivine $\left(\mathrm{Fo}_{85}\right.$ to $\left.\mathrm{Fo}_{81}\right), \mathrm{Cr}$ diopside 

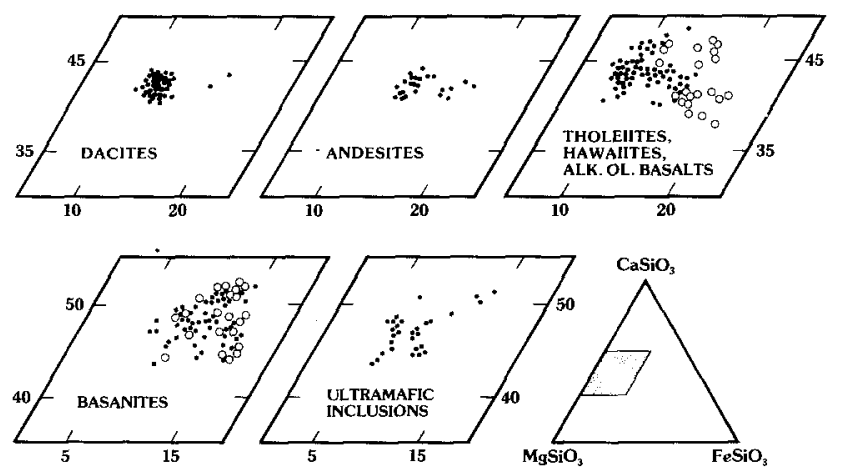

Fig. 2. Compositions of clinopyroxenes from MMVF dacites, and andesites, basalts, and ultramafic inclusions plotted in the pyroxene quadrilateral. Filled symbols are phenocrysts and open symbols are groundmass phases

and $\mathrm{Mg}-\mathrm{Al}$ chromites with olivine websterites also containing orthopyroxene $\left(\mathrm{En}_{85}, 2.5 \mathrm{wt} \% \mathrm{Al}_{2} \mathrm{O}_{3}\right)$. Spinel websterites contain diopsidic to augitic clinopyroxene, orthopyroxene $\left(\mathrm{En}_{80}, 2.3 \mathrm{wt} . \%\right.$ $\mathrm{Al}_{2} \mathrm{O}_{3}$ ), and chromian titanomagnetite.

\section{Intermediate and silicic rocks}

MMVF hornblende andesites, two-pyroxene dacites, and hornblende rhyodacites are mildly porphyritic with hyalopilitic textures. Plagioclase phenocrysts are abundant in all rocks except the Round and Table Mountain andesites, and are absent in the Mormon
Mountain andesites and dacites. Euhedral phenocrysts in the Hutch Mountain andesite exhibit strong reverse zoning ( $\mathrm{An}_{39}$ cores - $\mathrm{An}_{64}$ rims) and are accompanied by rare albite xenocrysts and quartz and magnetite fragments. In contrast, plagioclase phenocrysts of the Round and Table Mountain andesites are normally zoned $\left(\mathrm{An}_{63}-\mathrm{An}_{56}\right)$. Rhyodacites contain two groups of phenocrysts consisting of large (up to $1 \mathrm{~cm}$ ), oscillatory-zoned, rectangular crystals $\left(\mathrm{An}_{45}-\mathrm{An}_{30}\right)$ and small $(<3 \mathrm{~mm})$, normally-zoned, equant crystals $\left(\mathrm{An}_{33}-\mathrm{An}_{24}\right)$.

Andesites and rhyodacites contain abundant large amphibole phenocrysts. Compositions range from ferroan pargasitic hornblende (andesite) to ferroan pargasite (rhyodacites). Subhedral to euhedral augites (Fig. 2) with sector and subtle concentric zoning occur in the Mormon Mountain andesites and dacites. Augites in the andesites contain about twice as much $\mathrm{TiO}_{2}$ and $\mathrm{Al}_{2} \mathrm{O}_{3}$ ( 0.71 and $4.5 \mathrm{wt} \%$, respectively) as do augites in the dacites. Orthopyroxene phenocrysts of bronzite-to-hypersthene composition occur only in the pyroxene dacites and usually in glomerocrysts with clinopyroxene.

Groundmass are dominated by plagioclase and glass with accessory opaques, clinopyroxene, quartz, alkali feldspar, and apatite. Small laths of plagioclase range from $\mathrm{An}_{65-37}$ (andesites), $\mathrm{An}_{51-42}$ (dacites) to $\mathrm{An}_{40-25}$ (rhyodacaites). Light-to-dark-brown glass is only slightly devitrified and rhyolitic in composition with high $\mathrm{K}_{2} \mathrm{O} / \mathrm{Na}_{2} \mathrm{O}$ ratios (2-6). Opaque phases are either titanomagnetite or titanomagnetite (less rich in ulvospinel) and ilmenite.

\section{Geochemistry}

Sixty-nine samples from MMVF were selected for major element analysis and 34 were analyzed for trace elements. Sample locations

Table 1. Major element geochemistry and CIPW norms of representative MMVF basalts ${ }^{\text {a }}$

\begin{tabular}{|c|c|c|c|c|c|c|c|c|}
\hline \multirow[t]{2}{*}{ Sample } & \multirow{2}{*}{$\begin{array}{l}\text { O1. Nephelinite } \\
\text { MMT-24 }\end{array}$} & \multicolumn{2}{|l|}{ Basanite } & \multicolumn{2}{|c|}{ Alkali Ol. Basalt } & \multicolumn{2}{|l|}{ Hawaiite } & \multirow{2}{*}{$\begin{array}{l}\text { O1. Tholeiite } \\
\text { MMT-10 }\end{array}$} \\
\hline & & MMT-29 & MMT-11 & MMT-2 & MMT-34 & MMT-16 & MMT-5 & \\
\hline $\mathrm{SiO}_{2}$ & 43.50 & 45.40 & 48.92 & 47.77 & 47.73 & 51.86 & 52.64 & 50.81 \\
\hline $\mathrm{TiO}_{2}$ & 1.80 & 2.34 & 1.63 & 1.74 & 1.40 & 1.30 & 1.31 & 1.46 \\
\hline $\mathrm{Al}_{2} \mathrm{O}_{3}$ & 12.65 & 14.88 & 17.53 & 15.37 & 17.00 & 15.43 & 18.62 & 16.47 \\
\hline $\mathrm{FeO}$ & 9.89 & 10.76 & 9.26 & 9.58 & 11.47 & 8.39 & 8.72 & 9.61 \\
\hline $\mathrm{MnO}$ & nd & nd & 0.15 & 0.15 & nd & 0.14 & 0.13 & nd \\
\hline $\mathrm{MgO}$ & 14.57 & 10.59 & 5.75 & 9.99 & 7.33 & 8.63 & 4.39 & 7.13 \\
\hline $\mathrm{CaO}$ & 12.13 & 10.71 & 10.90 & 10.48 & 10.48 & 9.18 & 8.32 & 10.48 \\
\hline $\mathrm{Na}_{2} \mathrm{O}$ & 3.35 & 3.93 & 3.93 & 3.50 & 3.29 & 3.24 & 3.99 & 2.99 \\
\hline $\mathrm{K}_{2} \mathrm{O}$ & 1.23 & 0.65 & 1.45 & 0.77 & 0.98 & 1.36 & 1.36 & 0.71 \\
\hline $\mathrm{P}_{2} \mathrm{O}_{5}$ & 0.89 & 0.73 & 0.48 & 0.63 & 0.32 & 0.47 & 0.52 & 0.33 \\
\hline $\mathrm{Mg} \#^{\mathrm{b}}$ & 75.6 & 67.4 & 56.6 & 68.6 & 57.3 & 68.4 & 51.4 & 60.9 \\
\hline $\mathrm{CaO} / \mathrm{Al}_{2} \mathrm{O}_{3}$ & 0.96 & 0.72 & 0.62 & 0.68 & 0.62 & 0.60 & 0.45 & 0.63 \\
\hline \multicolumn{9}{|c|}{ CIPW normative mineralogy } \\
\hline Diop & 31.26 & 22.45 & 20.79 & 19.68 & 17.52 & 15.57 & 7.70 & 16.83 \\
\hline Hyp & 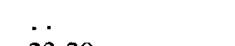 & $\ldots$ & $\cdots$ & $\ldots$ & . & 9.64 & 11.71 & 12.62 \\
\hline Oliv & 23.29 & 19.51 & 10.90 & 19.12 & 17.32 & 10.42 & 4.34 & 5.97 \\
\hline Or & 4.54 & 3.85 & 8.55 & 4.54 & 5.80 & 8.02 & 8.03 & 4.18 \\
\hline $\mathrm{Ab}$ & $\because$ & 14.59 & 20.96 & 21.46 & 20.98 & 27.45 & 33.73 & 25.32 \\
\hline An & 15.86 & 21.02 & 25.90 & 23.93 & 28.74 & 23.53 & 28.91 & 29.42 \\
\hline $\mathrm{Ne}$ & 15.34 & 10.12 & 6.68 & 4.44 & 3.69 & $\ldots$ & . & $\ldots$ \\
\hline Leu & 2.13 & $\ldots$ & . & $\ldots$ & . & . & . & . \\
\hline $\mathrm{Mt}$ & 2.39 & 2.60 & 2.24 & 2.32 & 2.77 & 2.03 & 2.11 & 2.32 \\
\hline Ilm & 3.41 & 4.44 & 3.09 & 3.30 & 2.66 & 2.46 & 2.49 & 2.77 \\
\hline Ap & 1.94 & 1.60 & 1.05 & 1.37 & 0.70 & 1.02 & 1.14 & 0.73 \\
\hline \multicolumn{9}{|l|}{$100 \mathrm{An}$} \\
\hline$\overline{\mathrm{An}}+\overline{\mathrm{Ab}}$ & 100.0 & 62.9 & 57.6 & 55.1 & 60.6 & 46.2 & 46.1 & 53.7 \\
\hline
\end{tabular}

a Normalized to $100.0 \%$ volatile free. Norms calculated with $\mathrm{FeO}=0.85 \Sigma \mathrm{FeO}$

b $\mathrm{Mg} \#=100 \mathrm{Mg} / \mathrm{Mg}+0.85 \sum \mathrm{FeO}$ 


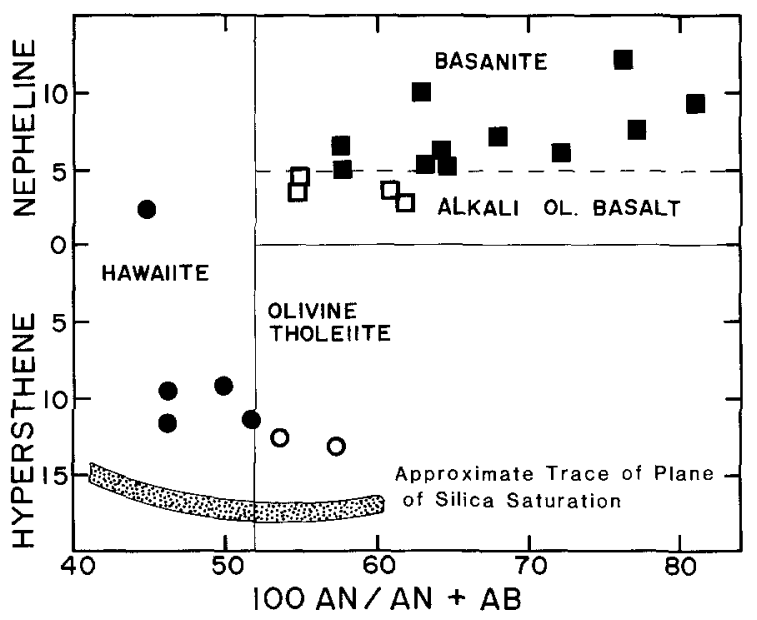

Fig. 3. Classification of representative MMVF basalts by normative hypersthene-nepheline vs. normative AN (100 An/An+Ab) (adapted from Best and Brimhall 1974). Filled squares-basanites, open squares-alkali ol. basalts, filled circles-hawaiites, open circlesol. tholeiites

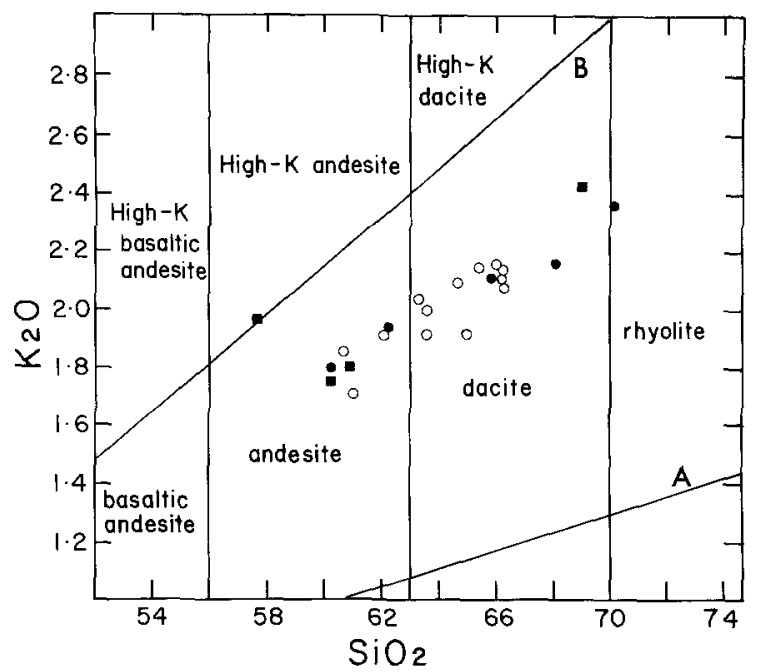

Fig. 4. Classification of MMVF intermediate and silicic rocks by $\mathrm{K}_{2} \mathrm{O}$ vs. $\mathrm{SiO}_{2}$ (Peccerillo and Taylor 1976). Circles-Mormon Mountain complex samples, squares-other MMVF samples. Filled symbols are analyses given in Table 3

Table 2. Trace element geochemistry of representative MMVF basalts

\begin{tabular}{|c|c|c|c|c|c|c|c|c|}
\hline \multirow[t]{2}{*}{ Sample } & \multirow{2}{*}{$\begin{array}{l}\text { Ol. Nephelinite } \\
\text { MMT-24 }\end{array}$} & \multicolumn{2}{|l|}{ Basanite } & \multicolumn{2}{|c|}{ Alkali Ol. Basalt } & \multicolumn{2}{|l|}{ Hawaiite } & \multirow{2}{*}{$\begin{array}{l}\text { Ol. Tholeiite } \\
\text { MMT-10 }\end{array}$} \\
\hline & & MMT-29 & MMT-11 & MMT-2 & MMT-34 & MMT-16 & MMT-5 & \\
\hline $\mathrm{Rb}$ & 24 & 22 & 15 & 11 & 7 & 21 & 16 & 6 \\
\hline $\mathrm{Ba}$ & 1,135 & 905 & 1,475 & 1,120 & 470 & 1,150 & 1,395 & 640 \\
\hline $\mathrm{Sr}$ & 1,065 & 1,040 & 1,015 & 1,040 & 540 & 960 & 1,120 & 565 \\
\hline $\mathrm{Pb}$ & 5 & 8 & 12 & 9 & 5 & 14 & 18 & 6 \\
\hline $\mathrm{La}$ & 92 & 51 & 45 & 41 & 19 & 42 & 52 & 26 \\
\hline$Y$ & 24 & 21 & 20 & 19 & 20 & 18 & 19 & 20 \\
\hline $\mathrm{Zr}$ & 240 & 218 & 144 & 171 & 120 & 146 & 165 & 111 \\
\hline $\mathrm{Nb}$ & 83 & 57 & 49 & 48 & 22 & 53 & 53 & 23 \\
\hline $\mathrm{Ga}$ & 14 & 17 & 17 & 17 & 19 & 16 & 21 & 18 \\
\hline $\mathrm{Cr}$ & 714 & 410 & 77 & 404 & 167 & 495 & 6 & 238 \\
\hline $\mathrm{Ni}$ & 366 & 216 & 46 & 190 & 108 & 249 & 17 & 87 \\
\hline V & 225 & 229 & 220 & 212 & 206 & 180 & 177 & 205 \\
\hline $\mathrm{Sc}$ & 29 & 24 & 23 & 22 & 27 & 23 & 19 & 28 \\
\hline $\mathrm{Cu}$ & 70 & 52 & 57 & 58 & 93 & 65 & 39 & 98 \\
\hline $\mathrm{Zn}$ & 83 & 93 & 73 & 83 & 88 & 72 & 95 & 90 \\
\hline
\end{tabular}

are given in Fig. 1. Major element analyses are each averages of 30 individual electron microprobe analyses of glasses from duplicate fusions on Mo strips in an Ar-pressurized atmosphere (Brown 1977; Nicholls 1974). Fused beads of BCR-1 and AGV-1 were used as internal standards. $\mathrm{Na}_{2} \mathrm{O}, \mathrm{K}_{2} \mathrm{O}$, and $\mathrm{P}_{2} \mathrm{O}_{5}$ were determined by atomic absorption for all 34 samples selected for trace element analysis. Selected samples were also analyzed in triplicate by atomic absorption to verify the fused bead analyses. Results obtained by these other procedures are in good agreement with the fused bead data. Abundances of $\mathrm{Ba}, \mathrm{Rb}, \mathrm{Sr}, \mathrm{Pb}, \mathrm{La}, \mathrm{Y}, \mathrm{Zr}, \mathrm{Nb}, \mathrm{Ga}, \mathrm{Cr}$, $\mathrm{Ni}, \mathrm{Sc}, \mathrm{V}, \mathrm{Cu}$, and $\mathrm{Zn}$ were determined by $\mathrm{x}-$ ray fluorescence spectrometry using the methods of Norrish and Chappell (1977). Only selected analyses are listed in the accompanying tables; additional analyses are available from the authors. Rare earth elements (REE), U, Th, Cs, Hf, Sn, and Mo were analyzed by spark source mass spectrography with the methods of Taylor and Gorton (1977). Sr-isotope ratios were measured at the Australian National University using Re triple filaments and normalized to ${ }^{86} \mathrm{Sr} /{ }^{88} \mathrm{Sr}=0.1194$ (McCulloch and Perfit 1981). Replicate measurements of NBS 987 yielded an average ${ }^{87} \mathrm{Sr} /{ }^{86} \mathrm{Sr}$ of $0.71033 \pm 6$.

\section{Basalts}

MMVF basalts are varied and include olivine nephelinite, basanite, alkali olivine basalt, hawaiite, and olivine tholeiite (classification of Best and Brimhall 1974) (Table 1; Fig. 3). $\mathrm{Mg}$ numbers $\left[100 \mathrm{Mg} /\left(\mathrm{Mg}+\mathrm{Fe}^{2+}\right)\right.$ with $\mathrm{Fe}^{2+}=0.85$ total Fe (Nicholls and Whitford 1976)] range between 67 and 54. Abundances of large-ion lithophile (LIL) elements (also $\mathrm{P}_{2} \mathrm{O}_{5}$ and $\mathrm{K}_{2} \mathrm{O}$ ) are similar among basanites, alkali olivine basalts, and hawaiites, but vary within each group by a factor of 3 (Table 2). Incompatible elements are lowest in the olivine tholeiites and highest in the olivine nephelinite. Contents of the compatible trace elements ( $\mathrm{Ni}, \mathrm{Cr}, \mathrm{Sc}$, and $\mathrm{V})$ are similar for the various basalt groups. $\mathrm{Ni}$ and $\mathrm{Cr}$ contents exhibit a slight positive correlation with $\mathrm{Mg}$ number whereas $\mathrm{Sc}$ and $\mathrm{V}$ do not vary systematically with $\mathrm{Mg}$ number. High $\mathrm{Ni}$ (366 ppm) and $\mathrm{Cr}(714 \mathrm{ppm})$ content of the olivine nephelinite (MMT-24) $(\mathrm{Mg}, \# 75)$ may be 
Table 3. Major element geochemistry and CIPW normative mineralogies of representative MMVF intermediate and silicic rocks ${ }^{\mathrm{a}}$

\begin{tabular}{|c|c|c|c|c|c|c|c|c|c|}
\hline \multirow[t]{2}{*}{ Sample } & \multicolumn{4}{|l|}{ Andesite } & \multicolumn{3}{|l|}{ Dacite } & \multicolumn{2}{|c|}{ Rhyodacite } \\
\hline & MMT-6 & MMT-21 & MMT-22 & MMT-25 & MMT-7 & MMT-9 & MMT-13 & MMT-3 & MMT-18 \\
\hline $\mathrm{SiO}_{2}$ & 60.05 & 59.92 & 60.70 & 57.90 & 62.06 & 66.04 & 68.03 & 69.97 & 68.80 \\
\hline $\mathrm{TiO}_{2}$ & 1.00 & 0.68 & 0.74 & 0.86 & 0.70 & 0.33 & 0.53 & 0.26 & 0.41 \\
\hline $\mathrm{Al}_{2} \mathrm{O}_{3}$ & 17.33 & 19.07 & 18.00 & 20.05 & 17.14 & 16.02 & 16.72 & 14.66 & 16.14 \\
\hline $\mathrm{FeO}$ & 5.60 & 5.04 & 4.91 & 5.44 & 5.41 & 4.30 & 3.10 & 3.31 & 2.73 \\
\hline $\mathrm{MnO}$ & nd & nd & ad & nd & 0.10 & $0.05^{\prime}$ & nd & nd & nd \\
\hline $\mathrm{MgO}$ & 3.69 & 2.09 & 2.95 & 1.80 & 2.63 & 2.02 & 1.12 & 1.33 & 1.60 \\
\hline $\mathrm{CaO}$ & 5.88 & 6.23 & 5.93 & 6.33 & 5.42 & 3.98 & 3.69 & 3.16 & 3.39 \\
\hline $\mathrm{Na}_{2} \mathrm{O}$ & 4.38 & 4.84 & 4.61 & 5.07 & 4.33 & 4.98 & 4.47 & 4.81 & 4.34 \\
\hline $\mathrm{K}_{2} \mathrm{O}$ & 1.79 & 1.75 & 1.79 & 1.98 & 1.94 & 2.09 & 2.17 & 2.35 & 2.44 \\
\hline $\mathrm{P}_{2} \mathrm{O}_{5}$ & 0.27 & 0.38 & 0.35 & 0.56 & 0.29 & 0.19 & 0.17 & 0.14 & 0.15 \\
\hline LOI & 0.32 & 0.76 & 0.53 & 0.07 & 0.76 & 0.09 & 0.58 & 0.85 & 1.80 \\
\hline $\mathrm{Mg} \#^{\mathfrak{b}}$ & 58.1 & 46.6 & 55.8 & 37.2 & 50.6 & 49.7 & 43.2 & 45.8 & 55.2 \\
\hline $\mathrm{K}_{2} \mathrm{O} / \mathrm{Na}_{2} \mathrm{O}$ & 0.41 & 0.36 & 0.39 & 0.39 & 0.45 & 0.42 & 0.49 & 0.49 & 0.56 \\
\hline \multicolumn{10}{|c|}{ CIPW normative mineralogy } \\
\hline Diop & 4.28 & 2.92 & 3.49 & 1.68 & 2.94 & 2.86 & $\ldots$ & 2.85 & \\
\hline Hyp & 13.42 & 9.79 & 11.41 & 9.95 & 11.81 & 9.27 & 6.31 & 6.17 & 7.07 \\
\hline Qtz & 8.58 & 7.61 & 9.07 & 3.58 & 12.39 & 16.19 & 22.98 & 23.35 & 23.28 \\
\hline Or & 10.56 & 10.34 & 10.59 & 11.71 & 11.46 & 12.35 & 12.84 & 13.90 & 14.24 \\
\hline $\mathrm{Ab}$ & 37.04 & 40.92 & 39.04 & 42.88 & 36.61 & 42.14 & 37.80 & 40.73 & 36.30 \\
\hline An & 22.36 & 25.16 & 23.13 & 26.11 & 21.61 & 15.19 & 17.31 & 11.45 & 15.74 \\
\hline $\mathrm{Mt}$ & 1.35 & 1.22 & 1.19 & 1.31 & 1.31 & 1.04 & 0.75 & 0.80 & 0.65 \\
\hline $\mathrm{Ilm}$ & 1.91 & 1.30 & 1.41 & 1.64 & 1.33 & 0.63 & 1.01 & 0.49 & 0.82 \\
\hline Ap & 0.59 & 0.83 & 0.77 & 1.23 & 0.63 & 0.42 & 0.37 & 0.31 & 0.33 \\
\hline Cor & . & $\ldots$ & $\ldots$ & $\ldots$ & . & . & 0.68 & $\ldots$ & 0.53 \\
\hline
\end{tabular}

a Normalized to $100.0 \%$, volatile free. CIPW norms calculated using $\mathrm{FeO}=0.85 \mathrm{FeO}$

b $\mathrm{Mg} \#=100 \mathrm{Mg} / \mathrm{Mg}+0.8 \Sigma \mathrm{FeO}$

Table 4. Trace element geochemistry of representative MMVF intermediate and silicic rocks

\begin{tabular}{|c|c|c|c|c|c|c|c|c|c|}
\hline \multirow[t]{2}{*}{ Sample } & \multicolumn{4}{|l|}{ Andesite } & \multicolumn{3}{|l|}{ Dacite } & \multicolumn{2}{|c|}{ Rhyodacite } \\
\hline & MMT-6 & MMT-21 & MMT-22 & MMT-25 & MMT-7 & MMT-9 & MMT-13 & MMT-3 & MMT-18 \\
\hline $\mathrm{Rb}$ & 16 & 14 & 16 & 18 & 19 & 21 & 23 & 21 & 16 \\
\hline $\mathrm{Ba}$ & 1,310 & 1,300 & 1,520 & 2,200 & 1,440 & 1,445 & 1,570 & 1,525 & 1,565 \\
\hline $\mathrm{Sr}$ & 1,145 & 1,530 & 1,520 & 1,390 & 1,220 & 1,110 & 1,065 & 985 & 715 \\
\hline $\mathrm{Pb}$ & 17 & 17 & 18 & 23 & 18 & 21 & 22 & 20 & 20 \\
\hline $\mathrm{La}$ & 42 & 47 & 51 & 70 & 39 & 44 & 29 & 23 & 21 \\
\hline $\mathrm{Y}$ & 17 & 13 & 11 & 17 & 12 & 11 & 7 & 8 & 4 \\
\hline $\mathrm{Zr}$ & 111 & 145 & 146 & 175 & 124 & 122 & 121 & 107 & 126 \\
\hline $\mathrm{Nb}$ & 33 & 28 & 33 & 69 & 29 & 38 & 19 & 17 & 12 \\
\hline $\mathrm{Ga}$ & 18 & 20 & 20 & 20 & 18 & 18 & 18 & 17 & 15 \\
\hline $\mathrm{Cr}$ & 34 & 3 & 21 & 21 & 26 & 27 & 23 & 17 & 17 \\
\hline $\mathrm{Ni}$ & 34 & 8 & 23 & 4 & 30 & 26 & 21 & 14 & 14 \\
\hline $\mathrm{V}$ & 121 & 69 & 74 & 83 & 102 & 64 & 49 & 41 & 44 \\
\hline $\mathrm{Sc}$ & 15 & 10 & 10 & 8 & 13 & 9 & 8 & 6 & 6 \\
\hline $\mathrm{Cu}$ & 36 & 14 & 12 & 12 & 22 & 26 & 24 & 14 & 12 \\
\hline $\mathrm{Zn}$ & 66 & 74 & 73 & 75 & 66 & 59 & 65 & 46 & 48 \\
\hline
\end{tabular}

the result of olivine $( \pm$ spinel) accumulation. Less than $50 \mathrm{ppm} \mathrm{Ni}$ is present in the basalts (MMT-5, MMT-20) with the lowest $\mathrm{Mg}$ numbers, which are also distinctive because of their high $\mathrm{Al}_{2} \mathrm{O}_{3}$ contents (>18 wt.\%).

\section{Intermediate and silicic rocks}

MMVF andesites, dacites, and rhyodacites (Table 3) are calcalkalic as defined by normative plagioclase versus
$\mathrm{Al}_{2} \mathrm{O}_{3}$ (Irvine and Baragar 1971), $\mathrm{K}_{2} \mathrm{O}$ versus $\mathrm{SiO}_{2}$ (Peccerillo and Taylor 1976) (Fig. 4), and the alkali-lime index (Peacock 1931). The Hutch Mountain andesite (MMT-25) is more alkalic, contains more $\mathrm{Al}_{2} \mathrm{O}_{3}(20 \mathrm{wt} . \%)$, and has a lower $\mathrm{Mg}$ number (37) than any other MMVF andesite. The MMVF suite as a whole is characterized by high $\mathrm{Ba}$ $(1,300-2,200 \mathrm{ppm})$ and $\mathrm{Sr}(715-1,530 \mathrm{ppm})$, but low Rb (14-23 ppm) and $\mathrm{Y}(4-17 \mathrm{ppm})$ (Table 4). Concentrations of $\mathrm{Ba}, \mathrm{Rb}, \mathrm{Pb}$, and $\mathrm{Zr}$ increase and $\mathrm{La}, \mathrm{Y}, \mathrm{Nb}$, and $\mathrm{Sr}$ 

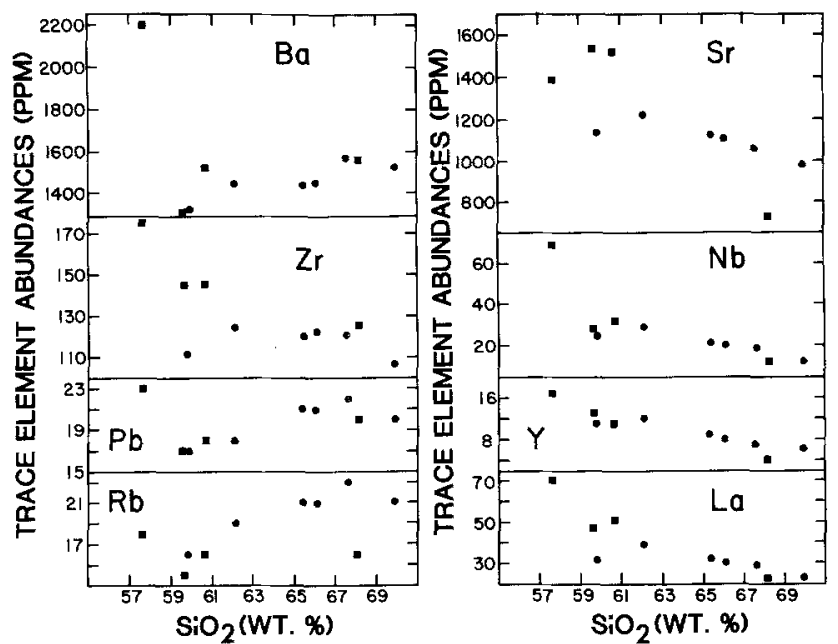

Fig. 5. Incompatible trace elements vs. $\mathrm{SiO}_{2}$ for MMVF intermediate and silicic rocks. Symbols are as in Fig. 4

Table 5. Additional trace elements of andesite, dacite, and rhyodacite from Mormon Mountain volcanic complex ${ }^{\text {a }}$

\begin{tabular}{|c|c|c|c|}
\hline & $\begin{array}{l}\text { Andesite } \\
\text { MMT-6 }\end{array}$ & $\begin{array}{l}\text { Dacite } \\
\text { MMT-9 }\end{array}$ & $\begin{array}{l}\text { Rhyodacite } \\
\text { MMT-3 }\end{array}$ \\
\hline $\mathrm{La}$ & 42.0 & 44.0 & 23.0 \\
\hline $\mathrm{Ce}$ & 73.1 & 82.2 & 44.4 \\
\hline $\operatorname{Pr}$ & 7.7 & 7.0 & 5.1 \\
\hline $\mathrm{Nd}$ & 27.3 & 24.1 & 18.7 \\
\hline $\mathrm{Sm}$ & 4.3 & 2.6 & 2.7 \\
\hline $\mathrm{Eu}$ & 1.20 & 0.76 & 0.88 \\
\hline $\mathrm{Gd}$ & 3.0 & 1.4 & 1.8 \\
\hline $\mathrm{Tb}$ & 0.49 & 0.23 & 0.21 \\
\hline Ho & 0.38 & 0.19 & 0.22 \\
\hline $\mathrm{Er}$ & 0.93 & 0.37 & 0.48 \\
\hline $\mathrm{Yb}$ & 0.75 & 0.20 & 0.32 \\
\hline $\mathrm{Ba}^{\mathrm{b}}$ & 1,310 & 1,445 & 1,525 \\
\hline Cs & 0.43 & 0.79 & 0.58 \\
\hline $\mathrm{U}$ & 1.47 & 1.56 & 0.95 \\
\hline $\mathrm{Th}$ & 5.0 & 5.6 & 2.7 \\
\hline $\mathrm{Zr}^{\mathrm{b}}$ & 111 & 122 & 107 \\
\hline $\mathrm{Hf}$ & 2.2 & 1.9 & 2.3 \\
\hline Sn & 0.85 & 0.70 & 0.70 \\
\hline Mo & 1.3 & 1.7 & 1.3 \\
\hline $\mathrm{SiO}_{2}($ wt. $\%)$ & 60.05 & 66.04 & 69.97 \\
\hline
\end{tabular}

a All abundances in ppm

b XRF values

decrease with increasing $\mathrm{SiO}_{2}$ contents (Fig. 5). The abundances of $\mathrm{Ba}, \mathrm{Pb}, \mathrm{La}, \mathrm{Y}$ and $\mathrm{Nb}$ are unusually high in the Hutch Mountain andesite. Chondrite - normalized REE abundances of Mormon Mountain andesite (MMT-6) and rhyodacite (MMT-3) are LREE-enriched and strongly fractionated $(\mathrm{La} / \mathrm{Yb}-=55$ and 73 ) (Table 5; Fig. 6). The rhyodacite contains less total REE than the andesite. REE's of the Mormon Mountain dacite (MMT-9) are more fractionated $(\mathrm{La} / \mathrm{Yb}=220)$ and cross both the andesite and the rhyodacite REE patterns (Fig. 6). Small positive Eu anomalies are present in the dacite and rhyodacite, but not in the andesite. Abundances of the compatible trace elements $(\mathrm{Ni}, \mathrm{Cr}, \mathrm{Sc}, \mathrm{V}, \mathrm{Cu}$, and $\mathrm{Zn}$ ) decline from andesites to rhyodacites.

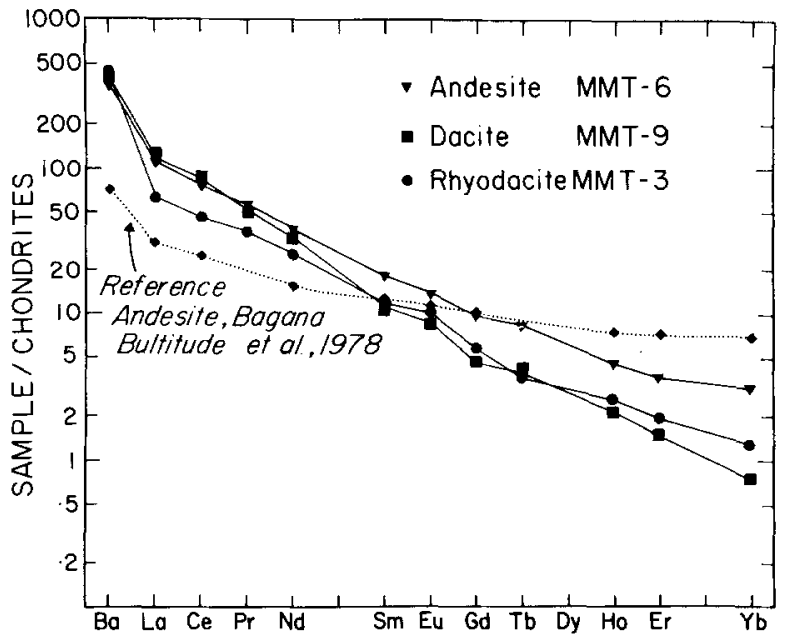

Fig. 6. Chondrite-normalized REE diagram for andesite, dacite, and rhyodacite from the Mormon Mountain complex. Reference andesite from Bagana is typical of island arc andesites and is shown for comparison

Table 6. ${ }^{87} \mathrm{Sr} /{ }^{86} \mathrm{Sr}$ isotopic ratios of samples from MMVF

\begin{tabular}{llccl}
\hline Sample & Rock type & ${ }^{87} \mathrm{Sr}{ }^{86} \mathrm{Sr}$ & $\mathrm{Sr}(\mathrm{ppm})$ & $\mathrm{Rb}$ (ppm) \\
\hline MMT-6 & hb. andesite & $0.70332 \pm 2$ & 1145 & 16 \\
MMT-7 & pyx. dacite & $0.70400 \pm 8$ & 1220 & 19 \\
MMT-3 & rhyodacite & $0.70363 \pm 5$ & 985 & 21 \\
MMT-22 & hb. andesite & $0.70378 \pm 4$ & 1520 & 16 \\
MMT-5 & hawaiite & $0.70367 \pm 7$ & 1120 & 16 \\
MMT-24 & ol. nephelinite & $0.70361 \pm 8$ & 1065 & 24 \\
SW-6 & pyx. granulite & $0.70372 \pm 1$ & 1013 & 0.5 \\
NBS 987 & standard & 0.71033 & $\ldots$ & $\cdots$ \\
\hline
\end{tabular}

\section{Strontium isotopes}

${ }^{87} \mathrm{Sr} /{ }^{86} \mathrm{Sr}$ isotopic ratios of two basalts and a nephelinite are within the range of 0.7036 to 0.7037 (Table 6). The andesite, dacite, and rhyodacite suite ranges from 0.70332 to 0.70400 . A pyroxene granulite xenolith from nearby Williams, Arizona is characterized by a low $\mathrm{Rb} / \mathrm{Sr}$ ratio $\left(5 \times 10^{-4}\right)$ and a $\mathrm{Sr}$ isotopic ratio of 0.70372 .

\section{Discussion}

\section{Basalts petrogenesis}

Our working hypothesis to account for the range of primitive basalt major and trace element geochemistry, despite their near identity in terms of ${ }^{87} \mathrm{Sr} /{ }^{86} \mathrm{Sr}$ ratio, involves variable degrees of partial melting of a common upper mantle source as the primary process. Secondary processes, such as fractional crystallization and assimilation of crustal rock types, have operated to varying extent on this range of primitive basalt types. These processes further diversify the geochemistry of MMVF basalts.

Primitive basaltic magmas that are little modified by extensive fractional crystallization or crustal contamination should have high $\mathrm{Mg}$ numbers (68 to 75 ) and high contents 
of compatible trace elements (e.g. Frey et al. 1978). MMVF alkali olivine basalts, basanites, and nephelinite with these characteristics contain abundant olivine phenocrysts, suggesting that they have fractionated olivine. Correction for this fractionation to a uniform $\mathrm{Mg}$ number of 71 (appropriate for a melt in equilibrium with a mantle of $\mathrm{Mg}$ number 89) requires adjustments in trace element abundances. For incompatible elements this is simply a dilution effect, however, adjustment of $\mathrm{Ni}, \mathrm{Cr}, \mathrm{Sc}$, and $\mathrm{V}$ abundances is complicated by the marked affinities of olivine and spinel for these elements (Frey et al. 1978). No attempt was made to model the abundances of these siderophile elements in the mantle source.

Different pressures, temperatures, and degrees of melting or source heterogeneities all affect melt composition. Assuming a uniform source, pyrolite (Ringwood 1966), the effects of differing degrees of partial melting can be evaluated (eg. Frey et al. 1978) for MMVF primitive basalts. The degree of partial melting may be defined by the $\mathrm{P}_{2} \mathrm{O}_{5}$ content of the primitive basalt and the pyrolite source $(0.06$ wt. \%). $\mathrm{TiO}_{2}$ and $\mathrm{CaO}$ contents of the basalt provide qualitative estimates of the degree of melting as both decrease as the percentage of melting increases. The $\mathrm{CaO} / \mathrm{Na}_{2} \mathrm{O}$ ratio increases as the degree of melting increases due to the dilution of jadeitic components in earlier formed melts by diopsidic components.

Although quantification is highly model dependent, the olivine nephelinite, with its low contents of $\mathrm{SiO}_{2}$ and $\mathrm{Al}_{2} \mathrm{O}_{3}$ and high contents of $\mathrm{MgO}, \mathrm{CaO}, \mathrm{TiO}_{2}$, and $\mathrm{P}_{2} \mathrm{O}_{5}$, should have resulted from small degrees of partial melting. The $\mathrm{CaO} / \mathrm{Na}_{2} \mathrm{O}$ ratio is high relative to the estimated degree of melting, but may be explained by bonding of $\mathrm{Ca}$ with $\mathrm{CO}_{3}$ in the melt (Frey et al. 1978). Experimental studies on olivine nephelinite indicate that the associated volatile phase must be $\mathrm{CO}_{2}$-rich relative to $\mathrm{H}_{2} \mathrm{O}$ during melting and consequently, the magmas must be enriched in $\mathrm{CO}_{3}$ (Brey 1978). Primitive basanites have higher $\mathrm{SiO}_{2}$ and $\mathrm{Al}_{2} \mathrm{O}_{3}$ contents and lower $\mathrm{MgO}, \mathrm{CaO}, \mathrm{TiO}_{2}$, and $\mathrm{P}_{2} \mathrm{O}_{5}$ contents than the olivine nephelinite, suggesting greater degrees of partial melting. Primitive alkali olivine basalts result from even greater degrees of partial melting than basanities. Given the model adopted, percentages of partial melting calculated vary from $7 \%$ for the olivine nephelinite to about $20 \%$ for the alkali olivine basalts. Although the absolute numbers may be substantially in error (c.f. McKenzie 1984), the overall sense of low to high percentages of melting in the order suggested seems probable.

Abundances of incompatible trace elements of primitive MMVF basalts correlate with the estimated degree of partial melting, decreasing as the amount of melting increases. Results of non-modal batch partial melting calculations suggest that the source of MMVF basalts was enriched in various incompatible elements relative to a model primitive mantle (Wood 1979). The order of this enrichment, from greatest to least, is $\mathrm{Nb}, \mathrm{Ba}, \mathrm{La}, \mathrm{Sr}, \mathrm{K}, \mathrm{Rb}, \mathrm{Pb}, \mathrm{Zr}$, and Y (Fig. 7). The causes of these enrichments are highly speculative but is note-worthy that strong enrichments of these elements are also present in the MARID suite of ultramafic nodules in kimberlites (Dawson and Smith 1977). Metasomatism of the mantle by $\mathrm{H}_{2} \mathrm{O}+\mathrm{CO}_{2}$ fluids enriched in incompatible elements (Best 1975; Boettcher et al. 1979), and veining of the mantle by highly alkalic melts (Wood 1979) have been suggested to account for these types of mantle enrichments.

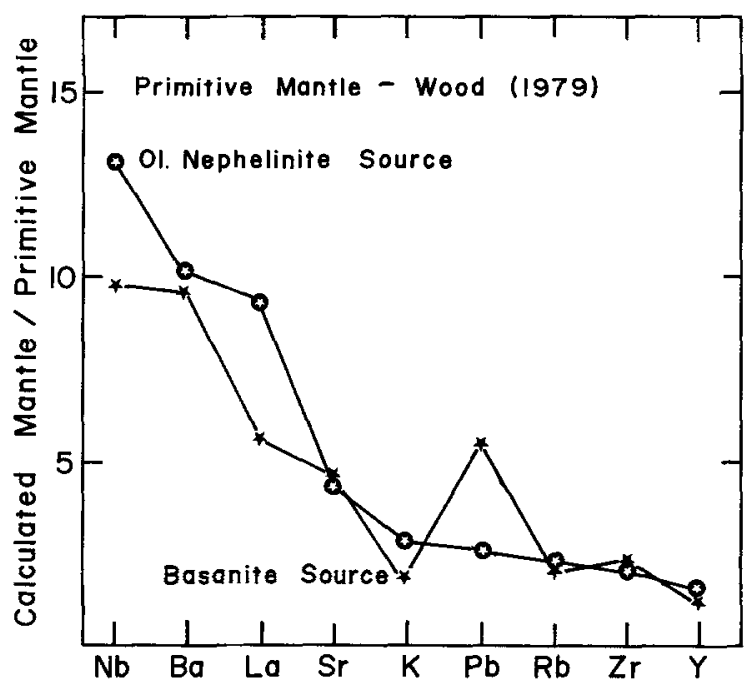

Fig. 7. Calculated enrichment (relative to primitive mantle (Wood 1979)] in the source of the ol. nephelinite and a basanite from MMVF

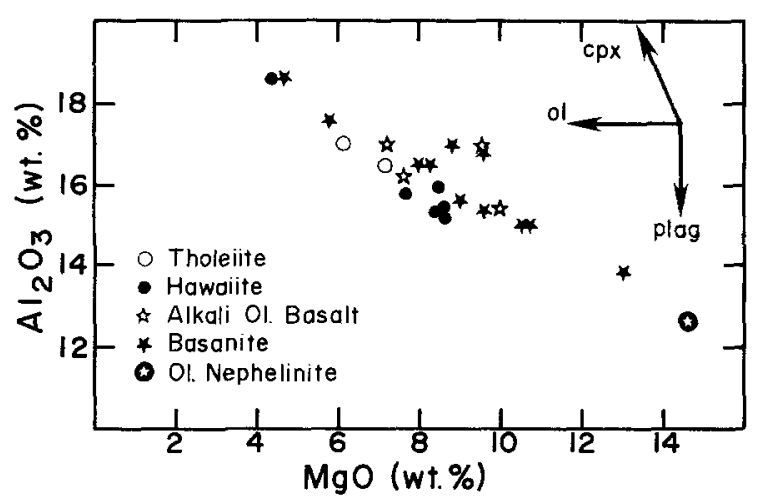

Fig. 8. $\mathrm{Al}_{2} \mathrm{O}_{3}$ vs. $\mathrm{MgO}$ for all MMVF basalts. Arrows indicate fractionation trends of liquids crystallizing clinopyroxene, olivine, and plagioclase. The MMVF trend is best explained by a combination of olivine and clinopyroxene fractionation and absence of plagioclase fractionation

\section{Fractional crystallization and crustal contamination}

Fractional crystallization of the different MMVF primitive basalts accounts for the variety of the MMVF basaltic suite. Decreases in $\mathrm{CaO}$ and increases in $\mathrm{Al}_{2} \mathrm{O}_{3}$ with decreasing $\mathrm{MgO}$ indicate strong olivine and clinopyroxene control during fractionation (Fig. 8). Plagioclase fractionation is relatively unimportant, and distinctly unlike that of many ocean floor and island arc basaltic suites. Quantitative models of fractional crystallization based on major element contents and petrologic characteristics are derived from least squares mixing calculations (Wright and Doherty 1970). These models suggest that moderate amount ( $8 \%$ to $32 \%$ ) of olivine, clinopyroxene, and spinel have been fractionated from primitive MMVF basalts. The $\mathrm{Cr}, \mathrm{V}$, and $\mathrm{Sc}$ contents are controlled by spinel and clinopyroxene fractionation. Extremely high Kd's of $\mathrm{Ni}$ and $\mathrm{Cr}$ for olivine and spinel, respectively, account for the observed three of fourfold drop in the concentrations of these elements (Sato 1977) prior to clinopyroxene fractionation. Decreases in Sc content in 


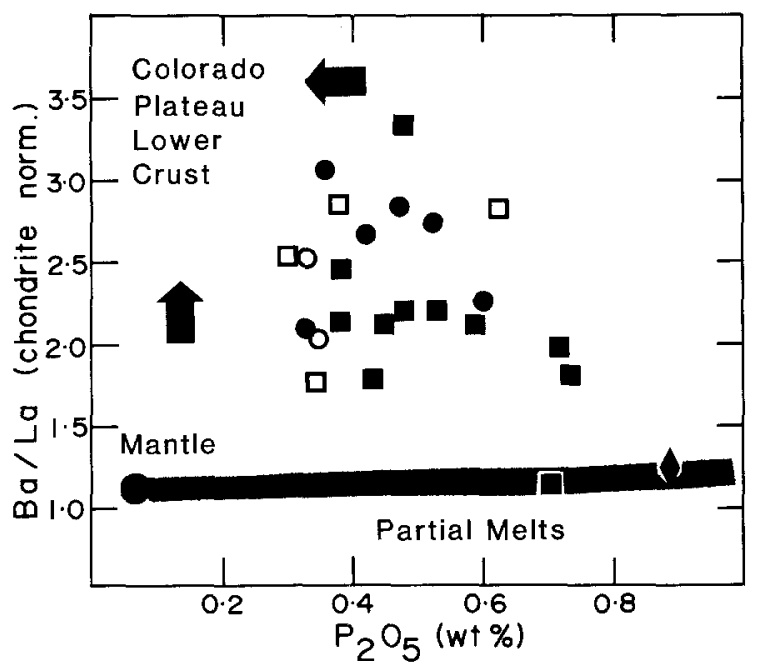

Fig. 9. Chondrite-normalized $\mathrm{Ba} / \mathrm{La}$ ratios vs. $\mathrm{P}_{2} \mathrm{O}_{5}$ for all MMVF basalts. The dark band represents the expected range of $\mathrm{Ba} / \mathrm{La}$ ratios of partial melts from a peridotitic mantle source (large circle). Estimates of possible lower crustal materials which might contaminate the basalts are shown by arrows. Symbols are in Fig. 3

the more evolved basalts are compatible with clinopyroxene fractionation (Irving 1978).

Rayleigh fractionation calculations (Minster et al. 1977) using constraints of least squares modeling do not successfully reproduce the observed characteristics for some incompatible trace elements of MMVF basalts. These results, which change only slightly with the choice of partition coefficients [from Arth (1976); Irving (1978)] require the derivative magmas to be less enriched in the highly incompatible elements ( $\mathrm{Rb}, \mathrm{Ba}, \mathrm{Sr}, \mathrm{K}, \mathrm{Nb}, \mathrm{La})$ than they actually are. This disparity is consistent with the complex, but geologically reasonable open-system magma chamber process described by O'Hara and Mathews (1981). However, the limited amount of basaltic volcanism and the strongly silicaundersaturated character of it in the MMVF seems unlikely to be products of a near steady-state magma chamber with periodic magma replenishments and evacuations.

The differences between calculated and actual abundances of some incompatible trace elements can also be explained by a combination of fractional crystallization and assimilation of incompatible element enriched crust (DePaolo 1981). Irregularities in the trends of incompatible trace elements of some primitive basalts with respect to degree of melting support this general concept. MMVF basalts were erupted through about $40 \mathrm{~km}$ of continental crust and this passage may have resulted in selective contamination (Watson 1982). If basalts are contaminated by melts derived from small amounts of crustal anatexis, $\mathrm{P}$ should be retained in the crustal residue in apatite due to its low solubility in felsic melts (Watson and Capobianco 1981). The presence of residual apatite in the source would also diminish the concentrations of REE in the melt. On the other hand, $\mathrm{Ba}, \mathrm{K}$ and $\mathrm{Pb}$ are concentrated in felsic melts being derived from the partial melting of alkali feldspar (Thompson et al. 1983). Watson (1982) has shown that assimilation of a feldspar melt in a basalt produces enrichments of various alkali elements over $\mathrm{Si}, \mathrm{Al}$, and the REE. These observations suggest that assimilation of crustal materials by basaltic magmas should result in selective enrich- ment of $\mathrm{Ba}, \mathrm{K}$, and $\mathrm{Pb}$ over $\mathrm{P}$ and the REE. Weaver and Tarney (1983) and Thompson et al. (1983) present several spidergrams of possible crustal contaminants that are consistent with these generalizations. In all cases, these contaminants are characterized by positive $\mathrm{Ba} / \mathrm{La}$ ratios (chondritenormalized) and low abundances of $\mathrm{P}$. The use of these parameters, $\mathrm{Ba} / \mathrm{La}$ or $\mathrm{Pb} / \mathrm{La}$ versus $\mathrm{P}_{2} \mathrm{O}_{5}$ may help assess the nature of crustal contamination in MMVF basalts. These ratios should decrease slightly as the degree of partial melting increases if the magmas are from a homogenous source. MMVF basalts exhibit trends opposite to those expected from only partial melting (Fig. 9) and although this can be due in part to clinopyroxene fractional crystallization, it is also consistent with crustal contamination.

\section{Basalt and andesite - co-genetic?}

Successful least-squares mixing models for several basaltandesite parent-daughter pairs are possible using either the observed basaltic or andesitic mineralogies as the fractionating assemblage. However, in using these models simple Rayleigh fractionation calculations are inconsistent for most of the incompatible trace elements. Almost all calculations predict excessive abundances of $\mathrm{Rb}, \mathrm{Pb}, \mathrm{K}, \mathrm{Ba}, \mathrm{Zr}$, $\mathrm{Nb}, \mathrm{La}$, and $\mathrm{Y}$ in the andesites. Calculated $\mathrm{La} / \mathrm{Y}$ ratios, which qualitatively model (LREE/HREE ratios, are variable and do not compare favorably with observed $\mathrm{La} / \mathrm{Y}$ ratios. Calculated $\mathrm{Sr}$ contents are more enriched than observed values. $\mathrm{Sr}$ isotopic data argue most convincingly against a simple co-genetic relationship between MMVF andesites and basalts as ${ }^{87} \mathrm{Sr} /{ }^{86} \mathrm{Sr}$ isotopic ratios of the basalts fall within a narrow range, 0.7036 to 0.7037 , with the ratios of the andesites being either higher or lower.

An exception to this general conclusion is the Hutch Mountain andesite (MMT-25). This andesite, which is geochemically distinctive from other MMVF andesites, probably formed by fractional crystallization of a basaltic parent. A model using a fairly evolved hawaiite ( $\mathrm{Mg}$ number $=52$ ) as the parent produces a close match to the observed major and trace element contents of the andesite. The occurrence of this andesite as a small plug within a hawaiite cinder cone supports this interpretation.

Combined wall-rock assimilation and fractional crystallization significantly enriches the highly incompatible elements in a magma over that expected from simple fractional crystallization (DePaolo 1981). Unlike MMVF basalt however, MMVF andesites are depleted in incompatible elements relative to the predictions of fractional crystallization models; combination of fractional crystallization with assimilation of incompatible element-enriched crustal material should accentuate this disparity. Thus, fractional crystallization combined with assimilation is probably an inappropriate mechanism to explain the origin of MMVF andesites.

\section{Origin of MMVF calcalkalic rocks - crustal anatexis}

An alternative petrogenetic hypothesis assumes andesite to be a primary magma. Some experimental petrologists have suggested that andesite could be generated by partial melting of amphibolite (Boettcher 1973), hydrous quartz eclogite (Ringwood 1974) or hydrous peridotite (Mysen and Boettcher 1975), but subsequent studies have concluded that calcalkalic low-Mg andesite can not be in equilibrium with a hydrous peridotite (Green 1976) or hydrous eclogite 


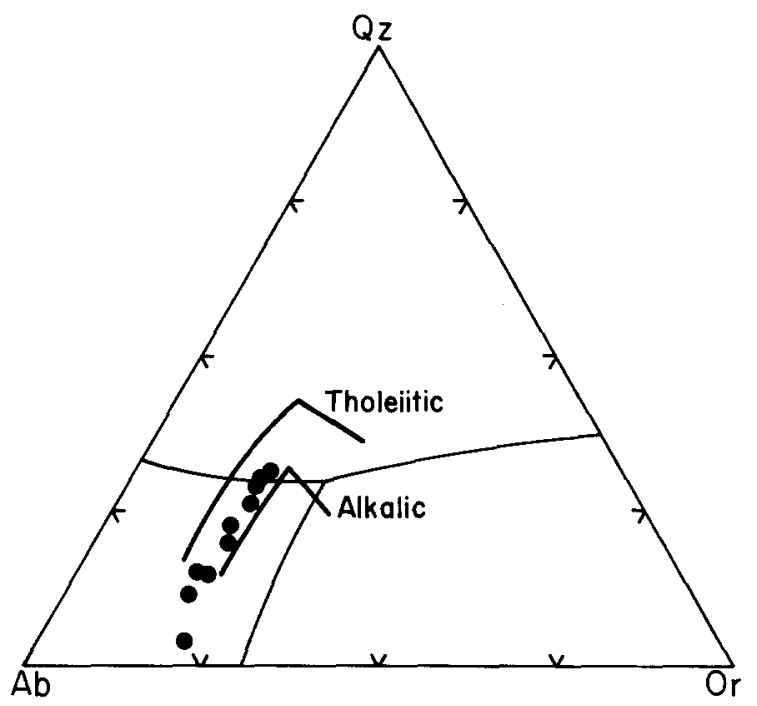

Fig. 10. AB-OR-QZ ternary projection of MMVF andesites, dacites, and rhyodacites. Similarities between the trend of this suite and the trends of partial melting of amphibolite (tholeiitic and alkalic composition - Helz 1976) suggests that the MMVF suite may result from different degrees of amphibolite fusion

Table 7. Input parameters for non-modal, sequential batch partial melting calculations for Mormon Mountain andesite

\begin{tabular}{lllll}
\hline $\begin{array}{l}\text { Proportions } \\
\text { of minerals } \\
\text { in source }\end{array}$ & Amphibole & Plagioclase & Apatite & Magnetite \\
\hline Initial & 0.500 & 0.470 & 0.015 & 0.015 \\
First melt & 0.300 & 0.650 & 0.035 & 0.015 \\
Second melt & 0.300 & 0.650 & 0.050 & 0.000 \\
Third melt & 0.800 & 0.200 & 0.000 & 0.000 \\
\hline
\end{tabular}

Apatite exhausted at $42.8 \%$ melting. End of first melting interval. Trace elements for andesite source calculated at $45.0 \%$ melting

at high pressures (Stern and Wyllie 1978; Gust 1982). Experiments on amphibolites (Holloway and Burnham 1972; Helz 1973/76) indicate that moderate degrees of melting $(30 \%-50 \%)$ produce liquids similar to MMVF andesites, dacites, and rhyodacites:(Fig. 10). These similarities suggest that amphibolite anatexis is of least a tenable hypothesis for the origin of the MMVF calcalkalic suite.

Trace element characteristics of a source for the Mormon Mountain andesite were calculated using an amphibolite anatexis model. Partial melting equations depend upon many poorly constrained variables including variations in source paragenesis, mode of melting, and trace element partitioning with respect to melt composition (Hanson 1980). Calculation of an amphibolite source uses input parameters loosely constrained by the experimental data of Helz (1976) (Table 7). The results of these calculations are shown in Fig. 11 where the source of the Mormon Mountain andesite is bracketed by compositions calculated using low-Si andesite and dacite partition coefficients (Hanson 1978). A generalized composition of the source of the Mormon Mountain andesite is moderately LREE-enriched and HREE-depleted. The contents of $\mathrm{Rb}, \mathrm{Sr}, \mathrm{Ba}, \mathrm{Y}, \mathrm{Zr}, \mathrm{Nb}$, and the REE's are not typical of model estimates for either upper

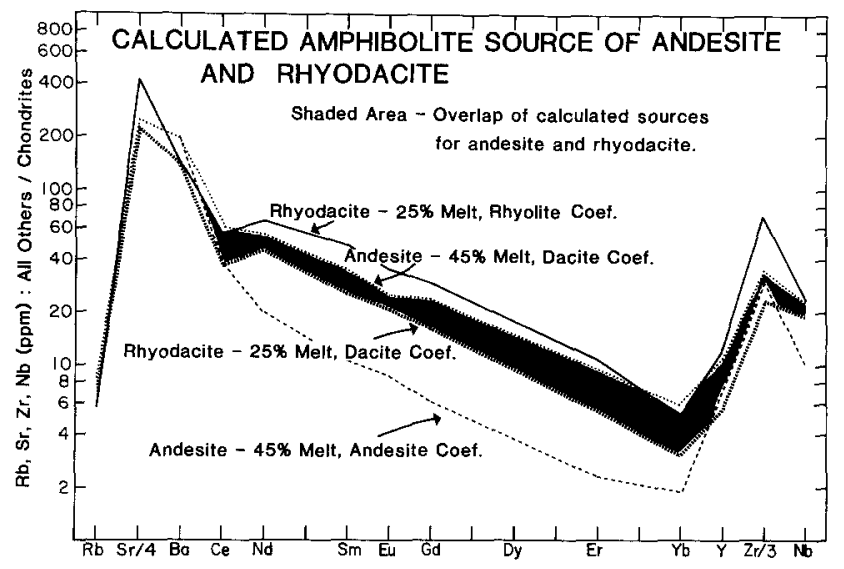

Fig. 11. Calculated amphibolite source(s) of andesite and rhyodacite of Mormon Mountain. Three sets of partition coefficients used in the calculation are indicated in the figure. The amount of overlap between the most likely coefficient sets represents the best approximation of the source

or lower crust (eg. Taylor and McLennan 1981). However, trace element analyses of crustal xenoliths indicate that the crust is much more complex than any of these generalized models and considerable variability in trace element composition is expected. The relatively low ${ }^{87} \mathrm{Sr} /{ }^{86} \mathrm{Sr}$ ratios of the MMVF andesites indicate that their source must have low $\mathrm{Sr}$ isotopic ratios resulting from a long-term depletion in $\mathrm{Rb}$. Low abundances of $\mathrm{Rb}$ in these lavas are also consistent with a Rb-poor source.

Different source mineralogies (pyroxene or garnet amphibolite) than the one used in the partial melting calculations show that addition of clinopyroxene at the expense of amphibole and plagioclase requires a more incompatible element-depleted source. Addition of garnet, replacing plagioclase, lessens the HREE-depletion of the source.

Mormon Mountain dacites and the MMVF rhyodacites could have been produced by smaller degrees of partial melting than those envisioned to produce andesitic magmas from amphibolite. Partial melting calculations for the trace elements suggest that andesite and rhyodacite could have been derived from a source with similar trace element characteristics (Fig. 11). Anomalies in $\mathrm{Zr}$ and the heavy REE abundances between the two sources may represent trace amounts of residual zircon in the rhyodacite source (Watson 1979). The petrogenesis of the dacite also may involve garnet or zircon as a residual phase in its source as suggested by its depleted HREE signature.

\section{Fractional crystallization in the calcalkalic suite}

Derivation of the dacites and rhyodacite of Mormon Mountain by fractional crystallization of the andesite is possible only if the proposed parent-daughter relationship is compatible with geological, temporal, petrologic, and geochemical characteristics of the suite. Different phenocryst assemblages of the andesite and dacites (wet versus dry), crossing REE patterns, and approximate constancy in contents of highly incompatible elements are inconsistent with a fractional crystallization origin for the dacites. On the other hand, these types of tests show that the rhyodacite could have been produced from andesite by fractional crys- 


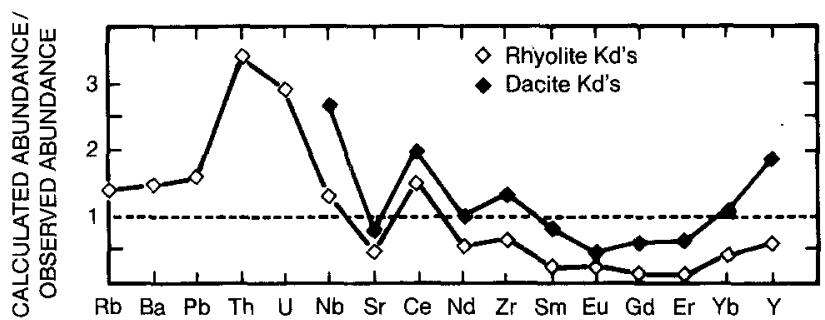

Fig. 12. Results from Rayleigh fractionation calculations for andesite (MMT-6) to rhyodacite (MMT-3) presented as the ratio of calculated abundances over observed abundances. The large compositional change between the parent-daughter pair is reflected in the use of different sets of partition coefficients. The closest approximation to the observed abundances in the rhyodacite (ratio = 1) is achieved by using dacite coefficients

tallization. Least squares calculations suggest that about $50 \%$ crystallization and removal of amphibole, plagioclase, apatite, and magnetite is required. Coarse-grained inclusions, dominated by amphibole and plagioclase, are found in the dacites, and may be products of this fractionation. Rayleigh fractionation calculations for incompatible trace elements neither confirm nor deny this hypothesis due to the extreme dependency of element partitioning between amphibole and melt on magma composition. The REE's (except $\mathrm{Ce}$ and $\mathrm{Yb}$ ) are best modeled using dacitic coefficients, but $\mathrm{Zr}, \mathrm{Nb}, \mathrm{Y}$, and $\mathrm{Sr}$ abundances are inconsistent with the data (abundances and Kd's) at hand (Fig. 12). Enrichments in $\mathrm{Rb}, \mathrm{Ba}, \mathrm{U}, \mathrm{Th}$, and $\mathrm{Ce}$ are predicted using either set of partition coefficients and contrast strongly with the observed depletions. In general, therefore, fractional crystallization of parental basalt magmas seems less likely as a genetic process in the generation of evolved melts of MMVF than melting of crustal sources.

\section{Conclusions}

The petrogenesis of MMVF is complicated and consists of two distinct aspects: the origin of the basalts, and the origin of the calcalkalic rocks. We have shown that these different suites are not likely co-genetic. Except in one case, MMVF andesites cannot be derived from MMVF alkalic basalts by fractional crystallization with or without crustal assimilation. Evidence for magma-mixing is not apparent. Therefore, the andesites are interpreted to be products of crustal anatexis. The only direct connection between basalts and andesites would seem to be the possible thermal contribution from hot basaltic magmas to the anatexis of the sources of the andesites.

The conclusions of this study are:

1. MMVF basalts are derived by varying degrees of partial melting of an incompatible element-enriched, metasomatized mantle. Fractional crystallization of olivine and clinopyroxene increases the compositional spectrum. Contamination by continental crust is subtle, and apparently restricted to highly incompatible elements.

2. Calcalkalic andesites, dacites, and rhyodacites may be generated by partial melting of a wet basaltic source (amphibolite) in the lower crust.
3. Rhyodacites may be produced by fractional crystallization of andesitic parents.

Acknowledgments. We thank MR Perfit, D Vaniman, MA Dungan, WP Leeman, and TL Grove for helpful comments and criticism and BW Chappell, MR Perfit, TM Harrison, and SH Stow for their analytical contributions. GE Ulrich, EW Wolfe, and RB Moore, U.S.G.S. Flagstaff (1977-78) suggested the project. Portions of this research were supported by a G.S.A. Summer Research Grant (2199-77), Rice University, The Australian National University, The National Research Council, and the Lunar and Planetary Institute. The Lunar and Planetary Institute is operated by the Universities Space Research Association under Contract No. NASW-3389 with the National Aeronautics and Space Administration. This paper is Lunar and Planetary Contribution No. 605.

\section{References}

Arculus RJ, Smith D (1979) Eclogite, pyroxenite, and amphibolite inclusions in the Sullivan Buttes Latite, Chino Valley, Yavapai County, Arizona. In: Boyd FR, Meyer HOA (eds) The mantle sample; inclusions in kimberlites and other volcanics, Am Geophys Union, Washington DC, pp 309-317

Arth JG (1976) Behaviour of trace elements during magmatic processes - a summary of theoretical models and their applications. J Res US Geol Surv 4:41-47

Best MG (1975) Migration of hydrous fluids in the upper mantle and potassium variation in calc-alkalic rocks. Geology $3: 429-432$

Best MG, Brimhall WH (1974) Late Cenozoic alkalic basaltic magmas in the western Colorado Plateau and the Basin and Range transition zone, USA and their bearing on mantle dynamics. Geol Soc Am Bull 85:1677-1690

Blackwell DD (1978) Heat flow and energy loss in the western United States. In: Smith RB, Eaton GP (eds) Cenozoic tectonics and regional geophysics of the western Cordillera. Geol Soc Am Mem 152:175-208

Boettcher AL (1973) Volcanism and orogenic belts - the origin of andesites. Tectonophysics 17:223-240

Boettcher AL, O'Neil JR, Windom KE, Stewart DC, Wilshire HG (1979) Metasomatism of the upper mantle and the genesis of kimberlites and alkali basalts. In: Boyd FR, Meyer HOA (eds) The mantle sample; inclusions in kimberlites and other volcanics. Am Geophys Union, Washington DC, pp 173-182

Brey G (1978) Origin of olivine melilities - chemical and experimental constraints. J Volcanol Getherm Res 3:61-68

Brown RW (1977) A sample fusion technique for whole rock analysis with the electron microprobe. Geochim Cosmochim Acta $41: 435-438$

Damon PE, Shafiqullah M, Leventhal J (1974) K - Ar chronology for the San Francisco volcanic field and rate of erosion of the Little Colorado River. In: Geology of northern Arizona Part 1. Regional Studies. Geol Soc Am Guidebook, Rocky Mt Sect Mtg, pp 221-235

Dawson JB, Smith JV (1977) The MARID (mica-amphibole-rutileilmenite-diopside) suite of xenoliths in kimberlites. Geochim Cosmochim Acta 41:309-323

DePaolo DJ (1981) Trace element and isotopic effects of combined wallrock assimilation and fractional crystallization. Earth Planet Sci Lett 53:189-202

Ehrenberg SN, Griffin WL (1979) Garnet granulite and associated xenoliths in minette and serpentinite diatremes of the Colorado Plateau. Geology 7:483-487

Frey FH, Green DH, Roy SD (1978) Integrated models of basalt petrogenesis: a study of quartz tholeiites to olivine melilitites from southeastern Australia utilizing geochemical and experimental petrological data. J Petrol 19:463-513

Green DH (1976) Experimental testing of 'Equilibrium' partial melting of peridotite under water-saturated, high-pressure conditions. Can Mineral 14:255-268 
Gust DA (1982) Experimental, petrologic, and geochemical studies on the origins of andesite. Unpubl Diss Austral Nat Univ

Gust DA, Arculus RJ, Moore RB, Wolfe EW, Ulrich GE (1984) Mantle-derived magma interaction with crust and the development of hybrid alkalic-calcalkalic lineages. Geol Soc Am Abstr $16: 526$

Hanson GN (1978) The application of trace elements to the petrogenesis of igneous rocks of granitic composition. Earth Planet Sci Lett 38:26-43

Hanson GN (1980) Rare earth elements in petrogenetic studies of igneous systems. Annu Rev Earth Planet Sci 8:371-406

Helz RT (1973) Phase relations of basalts in their melting range of $\mathrm{PH}_{2} \mathrm{O}=5 \mathrm{~kb}$ as a function of oxygen fugacity. Part I. Mafic phases. J Petrol 14:249-302

Helz RT (1976) Phase relations of basalts in their melting range at $\mathrm{PH}_{2} \mathrm{O}=5 \mathrm{~kb}$. Part II. Melt compositions. J Petrol 17:139193

Holloway JR, Burnham CW (1972) Melting relations of basalt with equilibrium water pressure less than total pressure. $J$ Petrol 13:1-29

Irvine TN, Barager WR (1971) A guide to the chemical classification of the common volcanic rocks. Can J Earth Sci 8:523-548

Irving AJ (1978) A review of experimental studies of crystal/liquid trace element partitioning. Geochim Cosmochim Acta 42:743-770

Keating SJ, Arculus RJ, Gust DA (1985) The role of amphibole cumulates in basalt evolution: Evidence from the San Francisco Peaks. Williams AZ. Eos 66:418

Lowder GG (1973) Late Cenozoic transitional alkali olivine-tholeiitic basalt and andesite from the margin of the Great Basin, southwest Utah. Geol Soc Am Bull 84:2993-3012

McCulloch MT, Perfit MR (1981) ${ }^{143} \mathrm{Nd} /{ }^{144} \mathrm{Nd},{ }^{87} \mathrm{Sr} /{ }^{86} \mathrm{Sr}$ and trace element constraints on the petrogenesis of Aleutian island arc magmas. Earth Planet Sci Lett 56:167-179

McGetchin TR, Silver LT (1972) A crustal-upper mantle model for the Colorado Plateau based on observations of crystalline rock fragments in the Moses Rock Dike. J Geophys Res 77:7022-7037

McKenzie DP (1984) The generation and compaction of partially molten rock. J Petrol 25:713-765

Minster JF, Minster JB, Allegre CJ, Treuil M (1977) Systematic use of trace elements in igneous processes: II. Inverse problem of fractional crystallization process in volcanic suites. Contrib Mineral Petrol 61:49-77

Moore RB, Wolfe EW, Ulrich GE (1976) Volcanic rocks in the eastern and northern parts of the San Francisco volcanic field, Arizona. J Res US Geol Surv 4:549-560

Mysen BO, Boettcher AL (1975) Melting of a hydrous mantle: II. Geochemistry of crystals and liquids formed by anatexis of mantle peridotite at high pressures and high temperatures as a function of controlled activities of water, hydrogen, and carbon-dioxide. J Petrol 16:549-593

Nicholls IA (1974) A direct fusion method of preparing silicate rock glasses for energy-dispersive microprobe analysis. Chem Geol 14:151-157

Nicholls IA, Whitford DJ (1976) Primary magmas associated with Quaternary volcanism in the western Sunda arc, Indonesia. In: Johnson RW (ed) Volcanism in Australasia, Elsevier Scientific Pub Co, Amsterdam, pp 77-90

Norrish K, Chappell BW (1977) X-ray fluorescence spectrometry. In: Zussman J (ed) Physical Methods of Determinative Mineralogy. Academic Press, London, pp 201-272
O'Hara MJ, Mathews RE (1981) Geochemical evolution in an advancing, periodically replenished, periodically tapped continuously fractionated magma chamber. J Geol Soc London $138: 237-277$

Peacock MA (1931) Classification of igneous rock series. J Geol 39:54-67

Peccerillo A, Taylor SR (1976) Geochemistry of Eocene calc-alkaline volcanic rocks from the Kastamonu area, northern Turkey: Contrib Mineral Petrol 58:63-81

Peirce HW, Damon PE, Shafiqullah M (1979) An Oligocene (?) Colorado Plateau edge in Arizona: Tectonophysics 61:1-24

Prodehl C (1970) Seismic refraction study of crustal structure in the western United States. Geol Soc Am Bull 81:2629-2646

Ringwood AE (1966) The chemical composition and origin of the Earth. In: Hurley PM (ed) Advances in Earth Sciences, MIT Press, Cambridge, MA, pp 287-356

Ringwood AE (1974) The petrological evolution of island are system. J Geol Soc London 130:183-204

Robinson HH (1913) The San Franciscan Volcanic Field Arizona. US Geol Surv Prof Pap 76:213p

Sato $H$ (1977) Nickel content of basaltic magma: identification of primary magmas and a measure of the degree of olivine fractionation. Lithos 10:113-120

Stern CR, Wyllie PJ (1978) Phase compositions through crystallization intervals in basalt-andesite- $\mathrm{H}_{2} \mathrm{O}$ at 30 kbar with implications for subduction zone magmas. Am Mineral 63:641-663

Stoeser DB (1973) Mafic and ultramafic xenoliths of cumulus origin, San Francisco Volcanic Field, Arizona. Unpubl Diss Univ Oregon

Taylor SR, Gorton MP (1977) Geochemical application of spark source mass spectrography - III. Element sensitivity, precision and accuracy. Geochim Cosmochim Acta 41:1375-1380

Taylor SR, McLennan SM (1981) The composition and evolution of the continental crust : rare earth element evidence from sedimentary rocks. Philos Trans R Soc London 301:381-399

Thompson RN, Morrison MA, Dickin AP, Hendry GL (1983) Continental flood basalts - Arachnids rule OK? In: Hawkesworth CJ, Norry MJ (eds) Continental basalts and mantle xenoliths, Shiva Publishing Ltd. Cheshire, UK, pp 158-185

Warren DH (1969) A seismic-refraction survey of crustal structure in central Arizona. Geol Soc Am Bull 80:257-282

Watson EB (1979) Apatite saturation in basic to intermediate magmas. Geophys Res Lett 6:937-940

Watson EB (1982) Basalt contamination by continental crust: some experiments and models. Contrib Mineral Petrol 80:73-87

Watson EB, Capobianco CJ (1981) Phosphorus and the rare earth elements in felsic magmas: an assessment of the role of apatite. Geochim Cosmochim Acta 45:2349-2358

Weaver BL, Tarney J (1983) Chemistry of the sub-continental mantle: inferences from Archean and Proterozoic dykes and continental flood basalts. In : Hawkesworth CJ, Norry MJ (ed) Continental basalts and mantle xenoliths. Shiva Publishing Ltd, Chershire, UK, pp 209-229

Wood DA (1979) A variably veined suboceanic upper mantle Genetic significance for mid-ocean ridge basalts from geochemical evidence. Geology 7:499-503

Wright TL, Doherty PC (1970) A linear programming and leastsquares computer method for solving petrologic mixing problems. Geol Soc Am Bull 81:1995-2008

Received April 4, 1985 / Accepted September 8, 1986 